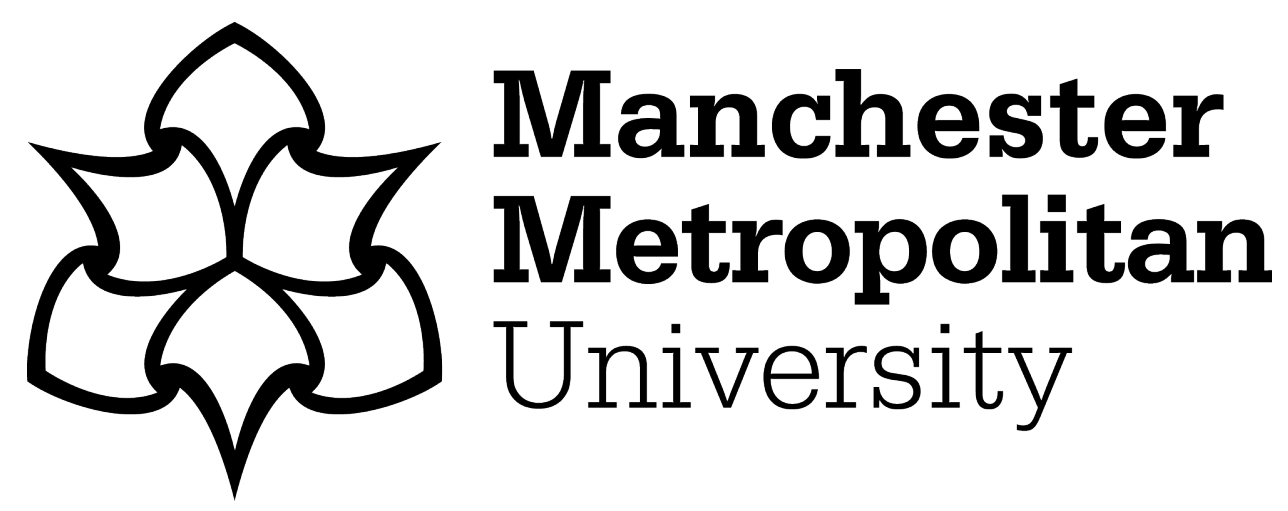

Gerber, Paula, Raj, Senthorun ORCID logoORCID: https://orcid.org/00000001-6972-9252, Wilkinson, Cai and Langlois, Anthony (2021) Protecting the rights of LGBTIQ people around the world: Beyond marriage equality and the decriminalisation of homosexuality. Alternative Law Journal, 46 (1). pp. 5-12. ISSN 1037-969X

Downloaded from: https://e-space.mmu.ac.uk/628634/

Version: Accepted Version

Publisher: SAGE Publications

DOI: https://doi.org/10.1177/1037969x20986658

Usage rights: Creative Commons: Attribution-Noncommercial-No Derivative Works 4.0

Please cite the published version 


\title{
Protecting the rights of LGBTIQ people around the world: Beyond marriage equality and the decriminalisation of homosexuality
}

\author{
Paula Gerber $\odot$
}

Faculty of Law, Monash University, Australia

\section{Senthorun Raj $\odot$}

School of Law, Keele University, UK

\section{Cai Wilkinson}

Faculty of Arts and Education, Deakin University, Australia

\author{
Anthony Langlois (1) \\ College of Business, Government and Law, Flinders University, Australia
}

\begin{abstract}
Discussions about the human rights of LGBTIQ people tend to centre around two vastly different issues, namely, marriage equality and the criminalisation of same-sex sexual conduct. However, looking only at these two high-profile issues ignores the many pressing concerns facing LGBTIQ people around the world. This article identifies and analyses eight other human rights issues that urgently need addressing, in order to respect the rights of LGBTIQ people across the globe.
\end{abstract}

\section{Keywords \\ LGBT, LGBTIQ, SOGII, gay/lesbian/transgender issues, human rights law, human rights}

In just a few decades, discussions regarding same-sex relationships have gone from taboo to almost fashionable.' In many countries, lesbian, gay, bisexual, transgender, intersex and queer (LGBTIQ) people are now able to marry. But in other parts of the world, engaging in same-sex sexual conduct and 'cross-dressing'

\footnotetext{
'For an analysis of the history of the experience of LGBTIQ people, including the days when gay men such as Oscar Wilde and Alan Turing were convicted of the crimes of sodomy and gross indecency, respectively, see, Claire L Hayward, 'Why LGBTQ History is Important' in Paula Gerber (ed), Worldwide Perspectives on Lesbians, Gays and Bisexuals (ABC-CLIO, 202I) vol I. For an example of the popularity of contemporary TV shows that have high profile LGBTIQ characters, see 'Orange is the New Black', which has run for seven seasons, is Netflix's most-watched original series, and nominee and winner of multiple Emmy awards. For other TV shows with lead LGBTIQ characters, see, '40 Great LGBTQ TV Shows to Stream Now', Rolling Stone (online, 22 June 2020) www.rollingstone.com/tv/tv-lists/lgbtq-tv-shows-watch-streaming-1012035/.
}

\section{Corresponding author:}

Professor Paula Gerber, Faculty of Law, Monash University, VIC 3800, Australia.

Email: Paula.Gerber@monash.edu 
(expressing a gender different to the sex assigned at birth) are still considered criminal acts, disorders or both. It seems that in 202I, LGBTIQ people are being discussed more than ever - in multiple fora including the United Nations, ${ }^{2}$ the media, religious bodies and within parliaments $^{3}$ - and views on whether they should be protected or persecuted are wildly divergent. ${ }^{4}$

Frequently, media coverage of LGBTIQ issues focuses on either marriage equality or the criminalisation of same-sex sexual conduct. In 2019, for example, wide media attention was given to decisions allowing samesex couples to marry in Taiwan ${ }^{5}$ and Ecuador, ${ }^{6}$ as well as Brunei's implementation of Sharia Law, which provided death by stoning as a punishment for anyone found guilty of engaging in same-sex sexual conduct. ${ }^{7}$

Furthermore, statistics pertaining to criminalisation of same-sex sexual conduct, and marriage equality, are frequently cited in the media, such as: 7I countries criminalise same-sex sexual conduct; ${ }^{8}$ II of these countries have the death penalty; ${ }^{9} 29$ countries have marriage equality; ${ }^{10}$ and two-thirds of these countries are in Western Europe." However, focusing on statistics means that the human faces behind the numbers are often missed. As an example, in Uganda - where engaging in same-sex sexual conduct remains a crime - 19 homeless LGBT people spent two months in prison in 2020, on spurious charges of violating COVID-19 curfew regulations. ${ }^{12}$ Having been forced out of their family homes, they had nowhere to go but a shelter; police arrested them for violating pandemic-related restrictions.

Marriage equality and the criminalisation of same-sex sexual conduct represent only two of the many human rights issues that LGBTIQ people continue to face in the 2 Ist century. However, by focusing predominantly on these two issues, other grave human rights concerns are ignored. This article seeks to contribute to filling this gap, by identifying and analysing the human rights violations that continue to negatively affect the ability of LGBTIQ people to live their lives with dignity and equality. Although these issues tend to receive less attention, they are as important as, if not more so than, marriage equality and decriminalisation of same-sex sexual conduct, since they have a very real impact on the dayto-day lives of LGBTIQ people.

\section{Laws prohibiting discrimination on the basis of sexual orientation, gender identity and expression}

When LGBTIQ people experience discrimination based on their sexual orientation, gender identity and expression (SOGIE), the law should provide redress. However, many countries either do not have anti-discrimination laws or, if they do, the law does not prohibit discrimination on the basis of SOGIE. For example, while South Korea's Constitution prohibits discrimination based on sex, religion or social status, and the Ministry of Justice has said this applies to SOGIE-based discrimination, these 'protections' have no enforcement power behind them. $^{13}$

While Australian federal, state and territory antidiscrimination laws protect against discrimination on the basis of SOGIE, the majority of these laws contain exemptions for religious organisations, which significantly limits their utility. As an example, with the exception of Queensland and Tasmania, all other states and territories allow religious schools to dismiss LGBTIQ staff because of their SOGIE, and to expel or refuse to enrol LGBTIQ students and/or students with same-sex parents. ${ }^{14}$

Furthermore, the situation in Australia for LGBTIQ people is set to get worse, rather than better, if the Religious Discrimination Bill 2019 is enacted. According to Luke Beck, the proposed Act contains

\footnotetext{
${ }^{2}$ For a list of UN resolutions addressing sexual orientation and gender identity, see Office of the High Commissioner for Human Rights at www.ohchr. org/en/issues/discrimination/pages/lgbtunresolutions.aspx.

${ }^{3}$ See, eg, Farrah Tomazin and Paul Sakkal, 'Liberals tussle over gay conversion laws as religious leaders split', The Age (online, 7 December 2020) www.th eage.com.au/politics/victoria/liberals-tussle-over-gay-conversion-laws-as-religious-leaders-split-20201 207-p56le8.html.

${ }^{4}$ Paula Gerber, 'LGBTIQ Rights Around the World: Marriage Equality and the Death Penalty Hide Wider Concerns', Australian Outlook (19 June 2019) www.internationalaffairs.org.au/australianoutlook/gbtiq-rights-around-the-world-marriage-equality-and-the-death-penalty-hide-wider-concerns/.

${ }^{5}$ Elaine Jeffreys and Pan Wang, 'Same-sex Marriage in Taiwan: Democratic Institutions Override Popular Conservativism, but Whither Marriage Equality?' (23 May 2019) www.internationalaffairs.org.au/australianoutlook/same-sex-marriage-taiwan-democratic-institutions-popular-conservativism/. ${ }^{6}$ 'Ecuador passes same-sex marriage in what LGBT campaigners say is a landmark week', ABC News (I3 June 2019) https://www.abc.net.au/news/201906-I 3/ecuador-approves-same-sex-marriage/ I 208246.

${ }^{7}$ Paula Gerber, 'Brunei wants to punish gay sex with death by stoning - can boycotts stop it?', The Conversation (16 April 2019) https://theconversation. com/brunei-wants-to-punish-gay-sex-with-death-by-stoning-can-boycotts-stop-it-I I 5352.

${ }^{8}$ Paula Gerber, 'Countries that Still Criminalise Homosexuality', Anti-Gay Laws (Web Page) https://antigaylaws.org/.

'Hristina Byrnes, '13 Countries where being gay is legally punishable by death', USA Today (online, 19 June 2019) https://www.usatoday.com/story/ money/2019/06/14/countries-where-being-gay-is-legally-punishable-by-death/39574685/.

${ }^{10}$ lbid.

I'David Masci \& Drew Desilver, 'A global snapshot of same-sex marriage', 20 October 2019 https://www.pewresearch.org/fact-tank/20I9/I0/29/globalsnapshot-same-sex-marriage/.

${ }^{12}$ Graham Reid, 'A Global Report Card on LGBTQ+ Rights for IDAHOBIT', Human Rights Watch (Web Page, I8 May 2020) https://www.hrw.org/news/ 2020/05/I8/global-report-card-lgbtq-rights-idahobit.

13'Fact Sheet: The State of LGBTQ Rights in Asia and the Pacific', NQAPIA (Blogroll, I2 February 20I8) https://www.nqapia.org/wpp/state-of-lgbtq-righ ts-in-asia-and-the-pacific/.

${ }^{14}$ See, eg, Equal Opportunity Act 2010 (Vic) s 83.
} 
provisions that are inconsistent with international human rights law, and essentially give religious people the 'right to be a bigot'. ${ }^{15}$ The Bill goes further than protecting people from discrimination on the basis of their religious beliefs; it grants them a licence to discriminate against others, including LGBTIQ people. ${ }^{16}$

As valuable as anti-discrimination laws are, they are not a panacea. Law reform is only ever one part of the solution. Changing laws will not improve the lives of LGBTIQ people if it is not accompanied by cultural change. South Africa provides a good illustration of this principle. South Africa was the first country to include sexual orientation as a prohibited ground of discrimination in a constitution, doing so in 1996. However, it is still one of the most dangerous places in the world to be LGBTIQ. Nigel Patel suggests that, "[ $t$ ]he law jumped miles ahead of society' and South Africa remains a violent and treacherous place for LGBTIQ people. ${ }^{17}$ Although comprehensive anti-discrimination laws are an important step in protecting the rights of LGBTIQ people, other measures, such as policy reform and education, are also necessary.

\section{Criminal laws to address hate crimes}

While civil remedies are useful to address LGBTIQ discrimination, they are not sufficient to fully protect LGBTIQ people. Criminal laws that address homophobic, biphobic and transphobic violence are also necessary.

Violence against LGBTIQ people is much broader than physical assault or sexual abuse - it manifests in acts that stigmatise, shame or otherwise disavow queer bodies because they disturb a social order that values reproductive heterosexuality. ${ }^{18}$ It also materialises in the policing of gender identities and expressions, because they disturb sex and gender categories that insist on maintaining a strict biological binary. ${ }^{19}$ For example, data on hate crimes in the UK from 2019/20 capture the pervasiveness of transphobic violence in that country: 40 per cent of trans people experienced abuse in public, with 91 per cent of those not reporting the most serious kinds of abuse to police. ${ }^{20}$ The most common reasons given for not reporting an incident involved 'That it was not worth it or nothing would happen or change' (48 per cent), or that 'it was not serious enough or it happens all the time' (54 per cent). ${ }^{21}$ In May 2019 , the Inter-American Commission on Human Rights referred a case of impunity in Honduras involving the 2009 assassination of Vicky Hernández, a transgender woman, to the Inter-American Court. ${ }^{22}$ Further, intersex people face infanticide in some parts of the world, where their bodies are stigmatised as 'witchcraft'. ${ }^{23}$

There is an urgent need for a strong response to this violence. This has happened in Brazil, where, in 2019, the Supreme Court held that, in the absence of legislation addressing homophobic and transphobic hate crimes, violence against LGBTIQ people can be punished under the country's racism law. ${ }^{24}$ However, there is still an absence of widespread and comprehensive laws dealing with violent anti-LGBTIQ hate crimes in the majority of countries.

While advocating for hate crime laws, it is important to recognise that carceral responses to social inequalities have to be adopted with caution. Queer and trans scholars note that punitive attempts to single out a few 'bad people' for punishment can further obscure the structural nature of homo/bi/transphobia and places already over-policed groups (such as Indigenous and black people) at risk of enhanced criminalisation. ${ }^{25}$ Therefore, it may be better to seek accountability for hate crimes through restorative justice and communitycentred initiatives, rather than prison sentences.

\section{Ban conversion therapy}

Conversion therapy is a practice based on a normative commitment to heterosexuality as the exclusively correct way to experience and express human sexual being, and a belief that all people have the developmental potential to become heterosexual and cisgender. ${ }^{26}$ In other words, a belief that LGBTQ people can be

\footnotetext{
${ }^{15}$ Luke Beck, 'Right to be a Bigot Hidden in the Government's Religious Freedom Bill', Sydney Morning Herald (online, 6 October 20I9) www.smh.com. au/national/right-to-be-a-bigot-hidden-in-the-government-s-religious-freedom-bill-20191004-p52xs7.html.

${ }^{16}$ See Equality Australia, Submission to the Attorney-General's Department, Religious Freedom Bills - first exposure draft consultation (2 October 2019) https://equalityaustralia.org.au/resources/submission-religious-discrimination-bill/.

${ }^{17}$ Kimon de Greef, 'The Unfulfilled Promise of LGBTQ Rights in South Africa', The Atlantic (2 July 2019) www.theatlantic.com/international/archive/ 2019/07/southafrica-lgbtq-rights/593050/.

${ }^{18}$ Stephen Tomsen, Violence, Prejudice and Sexuality (Routledge, 2009) 13.

${ }^{19}$ Dean Spade, Normal Life: Administrative Violence, Critical Trans Politics, and the Limits of Law (South End Press, $\left.201 \mathrm{I}\right)$ 7-9.

${ }^{20}$ Grahame Allen, Yago Zayed and Rebecca Lees, 'Hate Crime Statistics: House of Commons Library - Briefing Paper 8537' (I0 December 2020) Section $2.3 \mathrm{https} / / /$ commonslibrary.parliament.uk/research-briefings/cbp-8537/.

${ }^{21}$ Ibid.

22،LGBT Hondurans March against Hate', Human Rights Watch (Web Page, 23 May 20I9) https://www.hrw.org/news/20I9/05/23/lgbt-hondurans-marchagainst-hate.

${ }^{23}$ Morgan Carpenter, 'The OHCHR background note on human rights violations against intersex people' (2020) 28(I) Sexual and Reproductive Health Matters 2.

${ }^{24}$ 'Majority in Brazil's top court to make homophobia and transphobia crimes', BBC News, 24 May 2019 www.bbc.com/news/world-latin-america48391926.

${ }^{25}$ Sarah Lamble, 'Transforming carceral logics: 10 reasons to dismantle the prison industrial complex using a queer/trans analysis' in Nat Smith and Eric A Stanley (eds), Captive Genders: Trans Embodiment and the Prison Industrial Complex (AK Press, 20I I) 245.

${ }^{26}$ Christy Mallory, Taylor NT Brown and Kerith J Conron, 'Conversion Therapy and LGBT Youth: Update' (20I9) UCLA School of Law, Williams Institute https://williamsinstitute.law.ucla.edu/wp-content/uploads/Conversion-Therapy-Update-Jun-2019.pdf.
} 
'cured'. Conversion therapy is predominantly associated with faith communities who believe that LGBTQ people should either seek 'healing' or live celibate lives. ${ }^{27}$ Conversion therapy is known to be practiced in many jurisdictions around the world and is associated with a range of religious faiths. ${ }^{28}$

Psychological research has comprehensively discredited conversion therapy. The clinical evidence not only shows that the practice does not work, but also that it causes immense harm. ${ }^{29}$ Conversion therapy ranges from 'talking cures' through to 'aversion practices' such as the use of electrics shocks, or inducing nausea, vomiting or even paralysis. ${ }^{30}$ Jack Drescher notes that

[t]here is no empirical evidence that conversion therapy works. Because of ample evidence they do harm, conversion therapies are opposed by all mainstream mental health organizations, reminding therapists to first do no harm. ${ }^{31}$

Indeed, the levels of harm caused by such 'therapies' are so severe and demonstrable that they can be considered forms of torture or degrading treatment under international human rights law, particularly if compulsion is used, or it is used on minors. ${ }^{32}$

Due to such concerns, many countries have banned conversion therapy, particularly in the context of medical or health accreditation, or are working towards such restrictions. These efforts tend to be developed at provincial or regional levels and are well advanced in the $\mathrm{US}^{33}$ and also in Canada, ${ }^{34}$ the $\mathrm{UK}^{35}$ and parts of Europe. ${ }^{36}$ The situation in Australia is mixed. While some states have criminalised, or are moving towards criminalising, conversion therapy - including Queensland and the ACT - this tends to be limited to health professionals, thereby leaving religious bodies, where conversion therapy often occurs, unregulated. Victoria is an outlier in this regard, with the Change or Suppression (Conversion) Practices Prohibition Bill 2020 seeking to establish a civil response scheme within the
Victorian Equal Opportunity and Human Rights Commission that will, inter alia:

(i) promote understanding of the prohibition on change or suppression practices under this Act and matters relating generally to change or five suppression practices; and

(ii) consider and resolve reports of change or suppression practices; and

(iii) investigate serious or systemic change or suppression practices.

The Bill also creates offences in relation to engaging in change or suppression practices and certain related activities. $^{37}$

Given the diverse responses - or lack of responses to conversion practices across the country, it has been argued that, 'Australia needs to enact a ban that works in concert with federal human rights and antidiscrimination law, overseen by the Australian Human Rights Commission. ${ }^{38}$ Such laws should extend beyond the conduct of health practitioners to capture laypeople performing conversion therapy in faith-based settings, in the same way as the Victorian Bill.

Momentum to address the harms done by conversion therapy is building internationally, as illustrated by the most recent report of the UN Independent Expert on Protection against violence and discrimination based on sexual orientation and gender identity. On I May 2020, Victor Madrigal-Borlez submitted a report to the Human Rights Council that was devoted exclusively to the practice of conversion therapy. He found evidence of the practice in at "least 68 countries; ... its existence in all regions of the world, [and evidence that it is] "very common" in Africa and "somewhat common" in Latin America and the Caribbean and in Asia." ${ }^{39}$ The Independent Expert documented how conversion therapy violates human rights before making numerous recommendations, including that the practice of conversion therapy be banned, and that such bans must include a

\footnotetext{
${ }^{27}$ Timothy W Jones et al, Preventing Harm, Promoting Justice: Responding to LGBT Conversion Therapy in Australia (GLHV@ARCSHS/HRLC, 20I8) https:/ www.hrlc.org.au/reports/preventing-harm.

${ }^{28}$ Matthew Keating, 'Human Rights Program Hosts UN-Expert Consultation on so-Called “Conversion Therapy” Practices', Harvard Law Today (I3 March 2020) https://today.law.harvard.edu/human-rights-program-hosts-un-expert-consultation-on-so-called-conversion-therapy-practices/.

${ }^{29}$ Jones et al (n 27).

${ }^{30}$ Ibid 3; Mallory, Brown and Conron (n 26) 2.

${ }^{31}$ Keating (n 28).

${ }^{32}$ Ignatius Yordan Nugraha, 'The Compatibility of Sexual Orientation Change Efforts with International Human Rights Law' (20I7) 35(3) Netherlands Quarterly of Human Rights I76-92. https://doi.org/I0.I I77/092405 I9I7724654.

${ }^{33}$ Human Rights Campaign, 'The Lies and Dangers of Efforts to Change Sexual Orientation or Gender Identity' https://www.hrc.org/resources/the-liesand-dangers-of-reparative-therapy/.

34،Canada Presents Bill Banning Conversion Therapy’, BBC News, 9 March 2020 https://www.bbc.com/news/world-us-canada-5I773586.

35،Boris Johnson pledges ban on "gay conversion therapy”, BBC News, 20 July 2020 https://www.bbc.com/news/uk-politics-53477323.

36، Germany bans so-called gay conversion therapy for minors', CBS News, 18 December 2018 https://www.cbsnews.com/news/germany-bans-so-calledgay-conversion-therapy-for-minors/.

${ }^{37}$ Change or Suppression (Conversion) Practices Prohibition Bill $2020 \mathrm{~s} \mathrm{I}$.

${ }^{38}$ Larissa Sandy, Anastasia Powell and Rebecca Hiscock, 'Why Australia needs a national ban on conversion therapy', The Conversation (8 September 2020) https://theconversation.com/why-australia-needs-a-national-ban-on-conversion-therapy-I454I0.

39،Practices of so-called "conversion therapy", Report of the UN Independent Expert on protection against violence and discrimination based on sexual orientation and gender identity, I May 2020, A/HRC/44/53
} 
definition of the prohibited practices; a ban on public funds being used, directly or indirectly, to support such practices; and a ban on such practices being advertised or carried out in 'health-care, religious, education, community, commercial or any other settings, public or private'. ${ }^{40}$

\section{Address the persecution of transgender people}

Although LGBTIQ can be a useful umbrella term, it is important not to treat the LGBTIQ community as a single homogenous group and to recognise the unique human rights issues faced by the different groups that make up the acronym.

While trans visibility has increased of late, with celebrities such as Caitlyn Jenner and Laverne Cox becoming mainstream media stars, ${ }^{41}$ the rates of violence against transgender people have also increased. In 2009, the 'Trans Murder Monitoring' (TMM) project was developed, in response to the unacceptable rate at which trans people were being killed. The project publishes annual reports that document the number of hate-based killings of transgender people worldwide. ${ }^{42}$ Between I January 2008 and 30 September 2019, TMM recorded 3314 trans murders. $^{43}$ The most recent annual report recorded 331 new murders. The majority of these murders occurred in Brazil (I30), Mexico (63) and the US (30). ${ }^{44}$

While homicide is an extreme form of persecution, trans and gender-nonconforming people are also consistently targeted in other harmful ways. For example, the security and surveillance practices of law enforcement, present a constant source of concern for trans people. In Panama, where women and men have been required to remain quarantined on alternate days due to COVID-19, Human Rights Watch reports that, 'some transgender people have faced abuse from security officials, no matter which day they ventured out'. ${ }^{45}$

Another difficulty trans and gender-diverse people face is acquiring identification documents that reflect their gender identity. This often means that transgender people - particularly trans people of colour, low socioeconomic status, youth and immigrants - face extreme and disproportionate difficulty with security and policing agencies. ${ }^{46}$ Some jurisdictions require gender reassignment surgery before allowing a trans person to change the gender on their birth certificate. However, some jurisdictions have begun to remove such a requirement. Since May 2020, for example, trans people in Victoria have been able to change the gender on their birth certificate to female, male or another description, without having to undergo gender reassignment surgery. ${ }^{47}$

Trans people are also often subjected to hate speech and harassment, including misgendering and deadnaming. This is particularly acute on social media, and many major platforms have been reluctant to take any action against such harm due to concerns about free speech. However, in 2018, Twitter changed its terms of reference to prohibit 'targeting individuals with repeated slurs, tropes or other content that intends to dehumanize, degrade or reinforce negative or harmful stereotypes about a protected category'. ${ }^{48}$ This is a positive move towards protecting trans/ gender-diverse people from online hate speech.

Access to healthcare also remains a critical problem for trans and gender-diverse people. The ongoing pathologising of trans people 'creates abusive practices that violate trans people's right to dignity, bodily integrity, autonomy, and non-discrimination, fuelling stigma and violence'. ${ }^{49}$ Many trans people report experiencing transphobia from medical staff, with providers declining to offer services or actively harming clients. People consequently decline to seek support, or attempt various forms of self-treatment, with negative consequences for their health a commonplace outcome. ${ }^{50}$

Urgent action is needed to address the human rights breaches that transgender and gender-diverse people experience in all corners of the globe. Public education, law reform, policy change and community efforts are all needed to address the complex causes of anti-trans discrimination and violence.

\section{Address the invisibility of bisexuals}

While the ' $B$ ' is an accepted part of the 'LGBTIQ' acronym, bisexuality is often an invisible, excluded or silent

\footnotetext{
${ }^{40}$ Ibid [87].

${ }^{4 \mid}$ Frank Olito, 'I 6 Transgender Celebrities Who Are Changing Television', Insider (7 June 2020) https://www.insider.com/trans-celebrities-in-television$2019-10$.

${ }^{42}$ TGEU, 'A brief guide to monitoring anti-trans violence', Transrespect (Web Page, 3I March 2020) https://transrespect.org/en/brief-guide-to-monitor ing-anti-trans-violencel.

43،TMM Update Trans Day of Remembrance 2019', Transrespect (Web Page, I I November 20 I9) https://transrespect.org/en/tmm-update-trans-day-ofremembrance-2019/.

${ }^{44}$ Ibid.

${ }^{45}$ Reid (n 12).

${ }^{46}$ Toby Beauchamp, 'Surveillance' (20I4) I(I-2) Transgender Studies Quarterly 208-I0 https://doi.org/I0.12I5/23289252-2400037.

${ }^{47}$ James Hancock, 'Transgender community welcomes change to Victorian birth certificates', ABC News, 16 May 2020 https://www.abc.net.au/news/ 2020-05-I6/gender-diverse-victorians-welcome-birth-certificate-change//2254666.

${ }^{48}$ Nico Lang, 'Twitter Bans Misgendering and Deadnaming in Effort to Fight Transphobic Hate Speech', INTO (Web Page, 25 November 20 I8) https:// www.intomore.com/impact/twitter-bans-misgendering-and-deadnaming-in-effort-to-fight-transphobic-hate-speech.

${ }^{49}$ Lukas Berredo et al, 'Global Trans Perspectives on Health and Wellbeing', Transrespect (Web Page, December 20I8) https://transrespect.org/en/tvtpublication-series/

${ }^{50}$ lbid 6-9.
} 
sexual orientation. For example, if a woman has a male partner, she is usually assumed to be heterosexual; if she has a female partner, she is assumed to be a lesbian. Rarely do people consider that the woman may be bisexual. In such a case, the person may choose to 'pass' as either heterosexual or homosexual, or openly identify as such, and thus her bisexuality effectively becomes invisible. ${ }^{51}$ Kirsten McLean argues, however, that 'bisexuality is not completely invisible. Instead, when it is visible, it is significantly marginalized, often via inaccurate stereotyping and representations that render it an invalid and inauthentic sexual identity,. ${ }^{52}$ The term coined for this phenomenon is 'bisexual erasure': the pervasive denial of the existence or legitimacy of bisexuality. ${ }^{53}$

Humans are social creatures and the role of community is extremely important for our sense of well-being. To have a positive bisexual identity, Ann Fox argues that recognition, validation and support are essential preconditions. $^{54}$ Unfortunately, bisexual people are often unwelcome in both heterosexual and homosexual communities, which can make bisexual people feel rejected and excluded. ${ }^{55}$

In addition to the serious impact on bisexual people's sense of belonging and acceptance, bisexual erasure also leads to marginalisation, which in turn results in poorer physical and mental health outcomes. For example, UK research demonstrates that bisexuals have higher rates of hypertension and poorer self-rated health. ${ }^{56}$ Further, bisexuals have been found to be a 'high risk group for mental health problems and suicidal ideas and actions', ${ }^{57}$ which has been attributed to a number of factors, including poor social support, stigma and experiences of discrimination. ${ }^{58}$

In order to address bi-invisibility, bisexual people's voices need to be elevated, and the assumptions about the binary nature of sexuality - that people are either straight or gay - should be abandoned, giving way to more nuanced understanding about the variability of sexuality. Greater community support is essential to reduce the discrimination against, and isolation of, bisexual people and to improve their health and well-being.

\section{Prohibit non-essential surgery on intersex infants}

Intersex people are probably the least understood part of the LGBTIQ population. This is likely because intersex status is neither a sexual orientation nor a gender identity. Rather, intersex people are born with physical sex characteristics that don't fit medical and social norms for 'female' or 'male' body types. ${ }^{59}$

A human rights issue that is a priority for intersex people is the cessation of uninformed and nonconsensual surgery on intersex babies and children to 'normalise' their genitalia, such that they fit within medical gender norms. This harmful practice has been demonstrated to cause significant psychological harm to intersex people, and has been likened to female genital mutilation, a practice that is now almost universally condemned. $^{60}$

Malta became a pioneer for protecting the rights of intersex children in 2015, when it became the first country to enact laws recognising that all persons have the right to bodily integrity and physical autonomy. Malta made it unlawful for medical practitioners to conduct sex assignment treatment and/or surgical intervention on the sex characteristics of a minor, when treatment and/or intervention can be deferred until the person being treated can provide fully-informed consent. ${ }^{61}$ Other countries should follow Malta's example and prohibit uninformed and non-consensual genital surgery, to protect and uphold the rights of intersex people.

\section{Protect the rights of LGBTIQ asylum seekers and refugees}

Over the past four decades, an increasing number of jurisdictions have recognised asylum claims founded on persecution based on SOGIE. However, the prospect of successfully claiming asylum because of SOGIE-based persecution is limited.

The extent to which LGBTIQ refugees have been granted protection has been contingent on whether they subscribe to (cis/hetero)normative ideas of intimacy and identity. Initially, SOGIE claims were rejected on the basis that applicants could avoid persecution if they

\footnotetext{
${ }^{5 I}$ Kirsten McLean, 'Invisibility of Bisexuality' in Paula Gerber (ed), Worldwide Perspectives on Lesbians, Gays and Bisexuals (ABC-CLIO, 202I) vol I, 399.

${ }^{52}$ Ibid 392.

${ }^{53}$ Kenji Yoshino, 'The Epistemic Contract of Bisexual Erasure' (2000) 52(2) Stanford Law Review 353; see also 'Erasure of Bisexuality', GLAAD (Web Page) https://www.glaad.org/bisexual/bierasure.

${ }^{54}$ Ann Fox, 'Development of a Bisexual Identity' in Lani Ka'ahumanu and Loraine Hutchins (eds), Bi Any Other Name: Bisexual People Speak Out (Alyson, 1991) 34-5.

${ }^{55}$ McLean (n 5I) 400.

${ }^{56}$ SF-HRC, 'Bisexual Invisibility' 3; Bridget Gorman et al, 'A New Piece of the Puzzle: Sexual Orientation, Gender, and Physical Health Status' (20I5) 52 Demography I358, 1360.

${ }^{57}$ Anthony Jorm et al, 'Sexual Orientation and Mental Health: Results from a Community Survey of Young and Middle-Aged Adults' (2002) I80(5) British Journal of Psychiatry 423, 426.

${ }^{58}$ Ibid 426.

${ }^{59}$ See definition of intersex, 'What is intersex?', Intersex Human Rights Australia (Web Page) https://ihra.org.au/I8I06/what-is-intersex/.

${ }^{60}$ Cornelia Koch and Travis Wisdom, 'Surgery to make intersex children "normal” should be banned', The Conversation (5 July 2017$)$ https://th econversation.com/surgery-to-make-intersex-children-normal-should-be-banned-76952.

${ }^{61}$ ACT No XI of 20I5, I4 April 20I5, https://tgeu.org/wp-content/uploads/20I5/04/Malta_GIGESC_trans_law_20I5.pdf.
} 
remained 'discreet' about their sexual orientation or gender identity. While numerous courts around the world have rejected the use of 'discretion' reasoning, ${ }^{62}$ the number of successful applications by LGBTIQ asylum seekers has not increased. ${ }^{63}$

For many, seeking asylum means adhering to narrow Western assumptions about popular culture, gender expressions and sexual practices, or risk having a claim rejected. Lesbians who were previously in relationships with men are deemed 'inauthentic'; gay men who are religious are mistrusted if they are not seen to be suffering internal conflict between their faith and their sexual orientation; bisexuals are treated as capable of being in 'straight relationships' and thus not at risk; and trans people who refuse medical transition are treated with suspicion. ${ }^{64}$ Some LGBTIQ people have their credibility scrutinised because they delay disclosure of their sexual orientation or gender identity, often in circumstances of detention where disclosure could result in abuse. $^{65}$

Protecting the rights of LGBTIQ people within asylum seeking processes is more than a question of law reform. Although there are Guidelines regarding how claims for asylum based on SOGI should be assessed, these do not appear to have stimulated changes in practices. ${ }^{66}$ Respecting the rights of LGBTIQ asylum seekers requires nuanced country information reports about LGBTIQ experiences, training for decision-makers around cultural differences and assessing credibility, and bureaucracies that respect the dignity and humanity of LGBTIQ asylum seekers. ${ }^{67}$

\section{Provide safe and inclusive schools for LGBTIQ students}

Pursuant to the Convention on the Rights of the Child, all children have a right to education. For LGBTIQ students, this right is often violated because school is not a safe environment for them. Having a non-normative SOGIE may lead to bullying and discrimination at school. Numerous studies have demonstrated that such rights violations within schools have an effect on LGBTIQ children's performance and life chances. ${ }^{68}$

For schools to be a safe and inclusive space for LGBTIQ students, there must be reform to school policies and practices as well as changes to the curriculum and textbooks/resources. For example, LGBTIQ issues should be taught within the school curriculum, and LGBTIQ identities should be included in teaching materials. Such inclusion has been found to have demonstrable positive effects on the well-being of students. ${ }^{69}$ Teachers require training to help them develop the knowledge and skills needed to address LGBTIQ issues, and to teach students SOGI-related content. ${ }^{70}$ Teachers provide an important source of pastoral support for students, therefore having well-informed teachers is also important as a means of tackling homophobic/ biphobic/transphobic bullying.

Anti-bullying programs are needed to ensure that LGBTIQ students are safe within schools. The 'Safe Schools' program in Australia ${ }^{71}$ was recognised by the UN Human Rights Council as a good initiative 'to counter homophobia and transphobia in educational

\footnotetext{
${ }^{62}$ See, Minister for Immigration and Multicultural Affairs v Guo Ping Gui (1999) FCA I496; S395/2002 v MIMIA (2003) 2 I6 CLR 473; and HJ (Iran) and HT (Cameroon) v Secretary of State for the Home Department (20I0) UKSC 3I.

${ }^{63}$ Jenni Millbank, 'From Discretion to Disbelief: Recent Trends in Refugee Determinations on the Basis of Sexual Orientation in Australia and the United Kingdom' (2009) I3(2-3) The International Journal of Human Rights 39I.

${ }^{64}$ See, UKLGIG, 'Still Falling Short: The Standard of Home Office Decision-Making in Asylum Claims Based on Sexual Orientation and Gender Identity' (July 2018) https://uklgig.org.uk/wp-content/uploads/2018/07/Still-Falling-Short.pdf; Jaz Dawson, Queering constructivist international relations: Questioning identity-based human rights norms in sexual orientation-based refugee law (PhD Thesis, The University of Melbourne, 20I8) https://minerva-access.unimelb. edu.au/bitstream/handle/I I 343/22I 88I/Jaz \%20Dawson $\% 20$ Thesis $\% 20 \% 28$ Accepted $\% 29 \% 205.4 .20$ I 9 .pdf?sequence= I \&isAllowed=y; Jasmine Dawson and Paula Gerber, 'Assessing the Refugee Claims of LGBTI People' (2017) 29(2) International Journal of Refugee Law 292.

${ }^{65}$ Nuno Ferreira, 'Reforming the Common European Asylum System: Enough rainbow for queer asylum seekers?' (20I8) 2 GenIUS 25-42, 34.

${ }^{66} \mathrm{See}$, eg, UNHCR, Claims to Refugee Status based on Sexual Orientation and/or Gender Identity within the context of Article IA(2) of the I95 I Convention and/ or its 1967 Protocol relating to the Status of Refugees (23 October 2012) https://www.unhcr.org/509I36ca9.pdf; Looking through the Kaleidoscope: A Guide to Best Practice in Determining Applications for Refugee Status Based on Sexual Orientation, Gender Identity and Intersex Grounds (Kaleidoscope Australia Human Rights Foundation/K\&L Gates LLP, June 2016) http://www.kaleidoscopeaustralia.com/wp-content/uploads/20I5/05/Best-Practice-Guide-22nd-June2015.pdf.

${ }^{67}$ For a comprehensive discussion, see Jaz Dawson, 'Sexual Orientation-based Refugee Law: From Invisible to Credible?' in Paula Gerber (ed), Worldwide Perspectives on Lesbians, Gays and Bisexuals (ABC-CLIO, 202I) vol I, 372.

${ }^{68}$ See Reid (n 12); Maria Pallotta-Chiarolli, 'Bisexuality in Education' in Paula Gerber (ed), Worldwide Perspectives on Lesbian, Gays and Bisexuals (ABCCLIO, 202I) vol I, 327; Tiffany Jones, 'Lesbians and Gays in Education' in Paula Gerber (ed), Worldwide Perspectives on Lesbians, Gays and Bisexuals (ABCCLIO, 202I) vol I, 342

${ }^{69}$ Joseph C Kosciw et al, 'The Effect of Negative School Climate on Academic Outcomes for LGBT Youth and the Role of In-School Supports' (20I3) I2 (I) Journal of School Violence 45; Catherine Taylor and Tracey Peter, "We are not aliens, we're people, and we have rights": Canadian human rights discourse and high school climate for LGBTQ students' (201 I) 48(3) Canadian Review of Sociology 275; Burge et al 20I3).

${ }^{70}$ LGBTIQ Inclusive Education Index, 'The Indicators' (Web Page) http://www.education-index.org/the-indicators/

${ }^{71}$ The Safe Schools Coalition Australia (Web Page) www.safeschoolscoalition.org.au/who-we-are.
} 
institutions,. ${ }^{72}$ Unfortunately, between 2016 and 2018 the Safe Schools program was defunded by several state governments (for example, NSW and South Australia) as well as by the federal government, following a 'moral panic' about the program corrupting innocent children. ${ }^{73}$

Other countries are more successful than Australia in ensuring the protection of LGBTIQ children's right to education. By way of example, Scotland is set to implement LGBTQ+ inclusive lessons into the school curriculum in 2021, which will see students learning about same-sex marriage, same-sex parenting, homophobia, biphobia and transphobia. ${ }^{74}$ And South Africa is seeking to make its school textbooks more inclusive of sexual and gender minorities and same-sex families, after a study found that LGBTIQ people were referenced only twice across 38 textbooks in nine subjects. ${ }^{75}$

Ensuring LGBTIQ children are safe at school and receive an education that promotes respect for their rights is essential to creating societies in which the rights of sexual and gender minorities are adequately protected.

\section{Conclusion}

The human rights issues that LGBTIQ people face today are much broader than marriage equality and the criminalisation of same-sex sexual conduct. A holistic approach is needed to address the myriad human rights violations that stem from entrenched gender binaries, heteronormativity and homophobia/biphobia/ transphobia.

Law reform is necessary to strengthen antidiscrimination legislation and provide sanctions for hate crimes perpetrated against people because of their SOGI status. However, law reform alone is not enough. Further measures are required, including changes to education policies and practices, awareness-raising campaigns to increase understanding of and respect for sexual and gender minorities, and training for those working within the justice system, healthcare, the police and with asylum seekers.

It is vital that the broad range of human rights violations facing LGBTIQ people - civil and political, as well as economic, social and cultural - are acknowledged and addressed, if LGBTIQ people, living in diverse countries and cultures, are to enjoy lives of dignity and equality.

\section{Declaration of conflicting interests}

The author(s) declared no potential conflicts of interest with respect to the research, authorship, and/or publication of this article.

\section{Funding}

The author(s) received no financial support for the research, authorship, and/or publication of this article.

\section{ORCID iDs}

Paula Gerber (D) https://orcid.org/0000-0002-6292-6I54

Senthorun Raj (D) https://orcid.org/0000-000I-6972-9252

Anthony Langlois (D) https://orcid.org/0000-0002-3276-4086

Paula Gerber is a Professor in the Faculty of Law, Monash University, Australia.

Senthorun Raj is a Lecturer in the School of Law, Keele University, UK.

Cai Wilkinson is an Associate Professor in International Relations in the Faculty of Arts and Education, Deakin University, Australia.

Anthony Langlois is an Associate Professor in the College of Business, Government and Law, Flinders University, Australia.

\footnotetext{
${ }^{72}$ Human Rights Council, Discriminatory laws and practices and acts of violence against individuals based on their sexual orientation and gender identity: Report of the United Nations High Commissioner for Human Rights, UN Doc A/HRC/I9/4I (I7 November 20I I) para 77.

${ }^{73}$ Tania Penovic, 'Moral Panics and the Distortion of Human Rights' in Paula Gerber (ed), Worldwide Perspectives on Lesbians, Gays and Bisexuals (ABCCLIO, 202I) vol 2, 324.

${ }^{74}$ Ruth Foran, 'Scotland: First Country in the World to Include LGBT Education', Organization for World Peace (Web Page, 8 July 2020 ) https://theowp. org/scotland-first-country-in-the-world-to-include-lgbt-education/.

${ }^{75}$ Luiz DeBarros, 'Uproar over LGBTIQ inclusion in South African schools' textbooks', Mambaonline.com, I4 May 20 I 9 https://www.mambaonline.com/ 2019/05/I4/uproar-over-lgbtiq-inclusion-in-south-african-schools-textbooks/.
} 